\title{
THE EFFECT OF POTASSIUM ON THE HEART IN MAN
}

\author{
BY \\ WILLIAM A. R. THOMSON \\ From the Medical Unit, St. Thomas's Hospital \\ Received May 18, 1939
}

It is just one hundred years since Blake (1839) reported his " observations on the physiological effects of various agents introduced into the circulation." Among these were various salts of potassium, and he showed that when potassium carbonate, for instance, in doses of fifteen grains dissolved in six drachms of water was injected into the jugular vein in dogs, the animal was dead in forty-five seconds. He concluded that the action was a direct one upon the heart and that it was not harmful in therapeutic doses on account of the speed with which it was excreted by the kidneys.

During the intervening century it has been left to the physiologists to investigate the action of potassium salts upon the heart, work which has naturally been carried out upon the experimental animal. So far as the clinician was concerned, potassium, originally in the form of the citrate and the acetate and later as the chloride, rapidly came into favour as a diuretic, and, while there was a general feeling that in excess these salts might have their disadvantages, few, if any, experiments were carried out in man. Smillie in 1915 reported five cases of chronic nephritis to whom he had given 5 or 10 grammes of potassium chloride, and in one of these there was a sudden attack of intense cyanosis and prostration, preceded by præcordial pain, from which the patient took a fortnight to recover. From his work on potassium chloride as a diuretic, Blum (1920) recommended extreme caution in its use in patients with cardiovascular disease. Magnus-Levy (1920) also reported toxic effects from the use of potassium salts in a few patients with heart disease, and Webster (1927) stated that potassium salts by mouth " may cause irregularity of the heart and aggravation of symptoms of already existing renal or heart disease."

\section{Methods of Present Investigation}

As the result of the observation of certain changes in the electrocardiograms from patients that were receiving potassium salts, it was decided to carry out a more careful study of the effects of such salts upon the heart in man, not only to gain some information as to possible dangers in their therapeutic applica- 
tion, but also in an attempt to throw some light on their function in the ætiology of certain disorders of the heart.

The effect of potassium salts upon the heart has been studied in 24 patients, including the 5 already reported upon elsewhere (Thomson 1939) ; in addition the serum potassium and its alterations under certain conditions have been studied in a further 11 patients with heart disease. For the purpose of this paper, however, only the first 24 will be considered. This group included twelve patients with hypertension, two of whom had diabetes mellitus and one slight thyrotoxicosis ; five with advanced chronic nephritis; two with mitral stenosis and normal rhythm; one with coarctation of the aorta ; one with luetic aortic incompetence ; one with thyrotoxicosis ; one with the " menopausal syndrome" ; and one with allergy.

Potassium was given by mouth in the form of the citrate and the chloride, the usual dosage in the case of both salts being 5 grammes thrice daily at 8.30 a.m., 1.30 p.m., and 7 p.m., but several patients were given smaller amounts. Blood for the estimation of the serum cations was taken at noon, the patient having had nothing to eat since breakfast at eight; it was obtained from the antecubital vein without the use of stasis and the serum was separated one and a half hours later.

Electrocardiograms were practically all taken at the same time of dayshortly before the midday meal-with the patient in bed, and every care was taken to ensure that the standardization was uniform, i.e. 3 millivolts $=3 \mathrm{~cm}$. displacement of the fibre. In all instances they were taken both before and during the administration of potassium, and generally at least one was taken a week after it had been stopped.

The serum cations were estimated by the following methods ; potassium, Kramer and Tisdall (1921) as modified by Peters and Van Slyke (1932); sodium, Butler and Tuthill (1931); calcium, Kramer and Tisdall (1921) as modified by Clark and Collip (1925). The urease method was used for the estimation of the blood urea, and the hæmoglobin was estimated by means of the Haldane hæmoglobinometer, the blood always being taken from the ear without stasis at the same time of day.

\section{Results : (A) Potassium and the T Wave}

Potassium salts were administered to 24 patients ; changes in the $T$ wave were observed in 15 , but they were either absent or insignificant in 9 . The 15 that showed such changes were 5 with hypertension, 5 with chronic nephritis, and 5 others; details are given in Table I.

The change in the $T$ wave consisted of an increase in the height of the wave in 14 cases. This increase in height occurred in different leads, in one lead only or in all three, and in practically every case disappeared after potassium was stopped. Fig. 1 shows a typical example of the change obtained. In the fifteenth case the changes in the $\mathrm{T}$ wave were quite different in type, as can be seen from Fig. 2 (see page 273). 
TABLE I

InCRease of the Height of the T Wave in the Electrocardiogram With INCREaSe in the SERUM POTASSIUM

\begin{tabular}{|c|c|c|c|c|}
\hline \multirow[b]{2}{*}{$\begin{array}{l}\text { Case } \\
\text { Number }\end{array}$} & \multirow[b]{2}{*}{ Diagnosis } & \multicolumn{2}{|c|}{$\begin{array}{l}\text { Serum Potassium in } \mathrm{mg} \text {. per } \\
100 \text { c.c. }\end{array}$} & \multirow{2}{*}{$\begin{array}{c}\text { Electrocardiographic } \\
\text { Changes in the Height } \\
\text { of the } T \text { Waves }\end{array}$} \\
\hline & & $\begin{array}{c}\text { Before } \\
\text { Administration } \\
\text { of Potassium }\end{array}$ & $\begin{array}{c}\text { During } \\
\text { Administration } \\
\text { of Potassium }\end{array}$ & \\
\hline 7 & Malignant Hypertension & 11.9 & $18 \cdot 9$ & Increase \\
\hline 3 & Malignant Hypertension & $10 \cdot 1$ & $22 \cdot 9$ & Increase \\
\hline 1 & Essential Hypertension & $17 \cdot 2$ & $21 \cdot 8$ & Increase \\
\hline 8 & Essential Hypertension & $19 \cdot 6$ & $21 \cdot 5$ & Increase \\
\hline 2 & Essential Hypertension & $15 \cdot 5$ & $21 \cdot 2$ & Increase \\
\hline 4 & Chronic Nephritis $\quad$. & $20 \cdot 5$ & $31 \cdot 6$ & Increase \\
\hline 5 & Chronic Nephritis & $17 \cdot 0$ & $32 \cdot 8$ & Increase \\
\hline 9 & Chronic Nephritis & $22 \cdot 1$ & $25 \cdot 1$ & Increase \\
\hline 10 & Chronic Nephritis & $20 \cdot 7$ & $33 \cdot 1$ & Increase \\
\hline 22 & Chronic Nephritis & $22 \cdot 6$ & - & Increase \\
\hline 11 & Mitral Stenosis .. & $19 \cdot 1$ & $28 \cdot 9$ & Increase \\
\hline 12 & Aortic Incompetence & $17 \cdot 8$ & $31 \cdot 8$ & Increase \\
\hline 6 & Thyrotoxicosis .. $\quad$. & $16 \cdot 1$ & $23 \cdot 0$ & Increase \\
\hline 23 & Menopausal Syndrome. . & $16 \cdot 4$ & - & Increase \\
\hline 13 & Allergy $\ldots \quad \ldots$ & $19 \cdot 4$ & $21 \cdot 7$ & Increase \\
\hline 14 & Malignant Hypertension & $15 \cdot 1$ & $22 \cdot 2$ & No Increase \\
\hline 24 & Essential Hypertension. . & $15 \cdot 3$ & - & No Increase \\
\hline 15 & Essential Hypertension ; & & & \\
\hline 16 & Diabetes Mellitus $\cdots$ & $19 \cdot 7$ & $21 \cdot 6$ & No Increase \\
\hline 16 & $\begin{array}{l}\text { Essential Hypertension ; } \\
\text { Diabetes Mellitus }\end{array}$ & $15 \cdot 1$ & $18 \cdot 1$ & No Increase \\
\hline 17 & Essential Hypertension ; & & & \\
\hline & Thyrotoxicosis. . & $19 \cdot 1$ & $25 \cdot 3$ & No Increase \\
\hline 18 & Essential Hypertension. . & $18 \cdot 8$ & $20 \cdot 4$ & No Increase \\
\hline 19 & Essential Hypertension. . & $17 \cdot 0$ & $16 \cdot 7$ & No Increase \\
\hline 20 & Coarctation of Aorta . . & $16 \cdot 2$ & $17 \cdot 3$ & No Increase \\
\hline 21 & Mitral Stenosis . . & $15 \cdot 6$ & $15 \cdot 7$ & No Increase \\
\hline
\end{tabular}
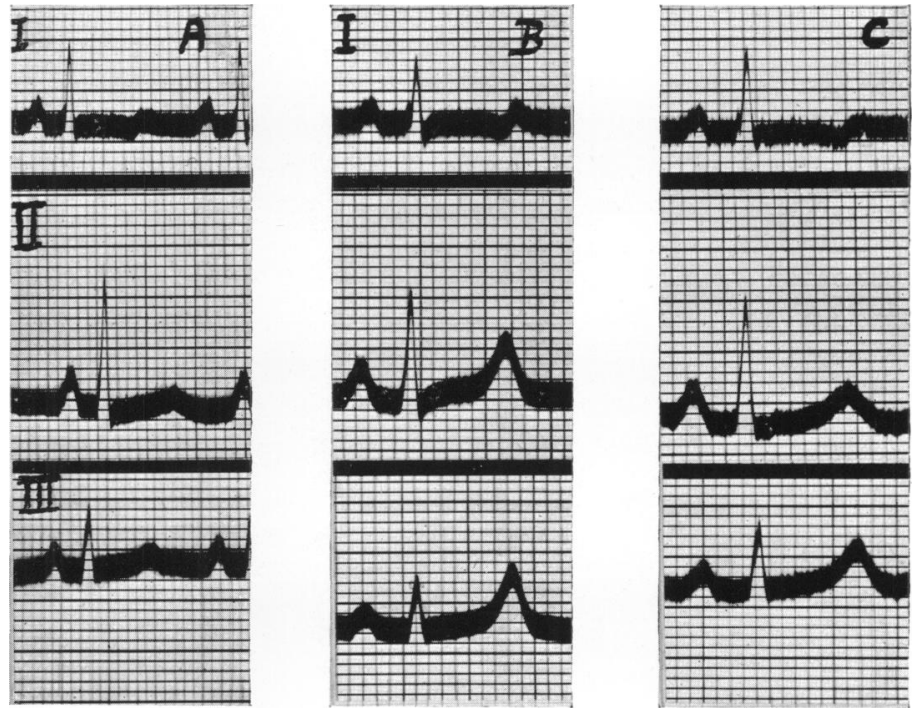

FIG. 1.-Electrocardiograms from case 4 , with chronic nephritis.

(A) Before administration of potassium salts.

(B) After $71 \mathrm{~g}$. of potassium chloride given during 7 days, showing heightened $\mathrm{T}$ waves in all leads (serum potassium increased from 20.5 to $31.6 \mathrm{mg}$. per 100 c.c.).

(C) After 14 days without any potassium salts, showing $\mathrm{T}$ waves diminished in height (serum potassium $21.4 \mathrm{mg}$. per 100 c.c.). 
In Table II the findings in six of these patients have been given in more detail. The increase in the height of T varied considerably, from 1 to $4 \mathrm{~mm}$., and in some cases it was more than doubled in height. This alteration in the height of the $T$ wave could not be correlated with any change in the rate of the heart, in the height or width of QRS, or in the length of the S-T segment.

TABLE II

More Detailed Effects of the Administration of Potassium in Six Cases

\begin{tabular}{c|c|c|c|c|c|c|c}
\hline $\begin{array}{c}\text { Number } \\
\text { of Days } \\
\text { from } \\
\text { Start }\end{array}$ & $\begin{array}{c}\text { Serum } \\
\text { Potas- } \\
\text { sium }\end{array}$ & $\begin{array}{c}\text { Serum } \\
\text { Sodium }\end{array}$ & $\begin{array}{c}\text { Serum } \\
\text { Cal- } \\
\text { cium }\end{array}$ & $\begin{array}{c}\text { Blood } \\
\text { Urea }\end{array}$ & $\begin{array}{c}\text { Haemo- } \\
\text { globin } \\
\text { per } \\
\text { cent. }\end{array}$ & $\begin{array}{c}\text { Height of T Wave } \\
\text { in EC. in mm. }\end{array}$ & Dosage of \\
Potassium Salts \\
\hline
\end{tabular}

Case 1. Essential Hypertension

\begin{tabular}{r|r|r|r|r|r|r|r|r|r}
0 & $17 \cdot 2$ & 323 & $10 \cdot 2$ & 31 & 102 & $2 \cdot 0$ & $2 \cdot 0$ & $-0 \cdot 5$ & Days 0-14, pot. \\
7 & $18 \cdot 3$ & 324 & $9 \cdot 5$ & 26 & 112 & $2 \cdot 0$ & $2 \cdot 0$ & $-0 \cdot 5$ & cit. 15 g. daily. \\
14 & $21 \cdot 3$ & 313 & $10 \cdot 0$ & 26 & 110 & $3 \cdot 0$ & $3 \cdot 0$ & $-1 \cdot 0$ & Days 7-14, pot. \\
28 & $21 \cdot 8$ & 325 & $10 \cdot 7$ & 24 & 88 & $4 \cdot 5$ & $2 \cdot 0$ & $-1 \cdot 5$ & chlor. 15g. daily.
\end{tabular}

Case 2. Essential Hypertension

\begin{tabular}{r|r|r|r|r|r|r|r|r|rr}
0 & $15 \cdot 5$ & 328 & $11 \cdot 4$ & 23 & 110 & $3 \cdot 0$ & $2 \cdot 5$ & $-0 \cdot 5$ & \multicolumn{2}{|c|}{ Days 0-14, pot. } \\
7 & $18 \cdot 5$ & 325 & - & 28 & 112 & $6 \cdot 5$ & $3 \cdot 5$ & $-2 \cdot 0$ & cit. 15 g. daily. \\
14 & $21 \cdot 2$ & 333 & $11 \cdot 0$ & 27 & 108 & $5 \cdot 0$ & $4 \cdot 5$ & $-0 \cdot 5$ & Days 7-14, pot. \\
21 & $15 \cdot 3$ & 326 & $10 \cdot 7$ & 21 & 102 & $2 \cdot 0$ & $2 \cdot 0$ & $-0 \cdot 5$ & chlor. 15 g. \\
& & & & & &
\end{tabular}

Case 3. Malignant Hypertension

\begin{tabular}{r|r|r|r|r|r|r|r|r|r}
0 & $10 \cdot 1$ & 310 & $10 \cdot 3$ & 16 & 86 & $-0 \cdot 5$ & $\mathrm{D}^{*}$ & $2 \cdot 0$ & Days 0-12, pot. \\
7 & $11 \cdot 8$ & 311 & $10 \cdot 5$ & 22 & 82 & $0 \cdot 0$ & $\mathrm{D}$ & $1 \cdot 5$ & cit. 15 g. daily. \\
12 & $22 \cdot 9$ & 306 & $11 \cdot 2$ & 33 & 98 & $1 \cdot 5$ & $4 \cdot 0$ & $2 \cdot 5$ & Days 7-12, pot. \\
24 & $7 \cdot 5$ & 307 & $10 \cdot 3$ & 20 & 84 & $-2 \cdot 0$ & $\mathrm{D}$ & $1 \cdot 5$ & $\begin{array}{l}\text { chlor. 15 g. } \\
\text { daily. }\end{array}$
\end{tabular}

Case 4. Chronic Nephritis

\begin{tabular}{|c|c|c|c|c|c|c|c|c|c|c|}
\hline 0 & - & 一 & - & - & - & D & $1 \cdot 0$ & $1 \cdot 0$ & Days & $5-12$, pot. \\
\hline 2 & $20 \cdot 5$ & - & $9 \cdot 3$ & 143 & 65 & 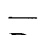 & - & - & cit. & $71 \mathrm{~g}$. \\
\hline 12 & $31 \cdot 6$ & - & $11 \cdot 0$ & 148 & 56 & D & $5 \cdot 0$ & $5 \cdot 0$ & & - \\
\hline 26 & $21 \cdot 3$ & - & $9 \cdot 6$ & 180 & 55 & D & $3 \cdot 0$ & $3 \cdot 5$ & & \\
\hline
\end{tabular}

Case 5. Chronic Nephritis

\begin{tabular}{|c|c|c|c|c|c|c|c|c|c|}
\hline 0 & $17 \cdot 0$ & - & $9 \cdot 6$ & 62 & 96 & $-2 \cdot 0$ & $\mid-1 \cdot 5$ & 0.5 & Days $1-8$, pot. \\
\hline 8 & 32. & 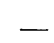 & 9.9 & 70 & 92 & 1.0 & $2 \cdot 0$ & 1.5 & Days $6-8$, pot. \\
\hline & 16 . & & 9.6 & 81 & 82 & 1.0 & -0.5 & -1.5 & $\begin{array}{l}\text { chlor. } 15 \mathrm{~g} \text {. } \\
\text { daily. }\end{array}$ \\
\hline
\end{tabular}

Case 6. Thyrotoxicosis

\begin{tabular}{|c|c|c|c|c|c|c|c|c|c|}
\hline 0 & $16 \cdot 1$ & - & $10 \cdot 8$ & 30 & 92 & $1 \cdot 0$ & $1 \cdot 5$ & $1 \cdot 0$ & Days $0-6$, pot. \\
\hline $\begin{array}{l}11 \\
21\end{array}$ & $\begin{array}{l}23 \cdot 0 \\
19 \cdot 4\end{array}$ & - & $\begin{array}{r}10.8 \\
9.9\end{array}$ & $\begin{array}{l}44 \\
26\end{array}$ & $\begin{array}{l}102 \\
105\end{array}$ & $\begin{array}{l}2 \cdot 0 \\
1 \cdot 5\end{array}$ & $\begin{array}{l}4 \cdot 0 \\
2 \cdot 0\end{array}$ & $\begin{array}{l}1.0 \\
1.5\end{array}$ & $\begin{array}{l}\text { Days } 7-11 \text {, pot. } \\
\text { cit. } 15 \mathrm{~g} \text {. daily, } \\
\text { pot. chlor. } 15 \mathrm{~g} \text {. } \\
\text { daily. }\end{array}$ \\
\hline
\end{tabular}

* $\mathrm{D}=$ Diphasic. 
The amount of potassium salts ingested before this change was produced varied considerably. In one patient it occurred after only $20 \mathrm{~g}$. of the citrate given during four days. In others, $210 \mathrm{~g}$. of the citrate and $105 \mathrm{~g}$. of the chloride given over a period of two weeks did not produce it. Of the 15 patients who showed changes in the $T$ wave, 7 received the citrate alone, 7 received both citrate and chloride simultaneously and 1 received only the chloride, while of the 9 who showed no such change, 7 received the citrate alone and 2 received both salts.

The concentration of serum potassium at which this change occurred was most inconstant, a more constant figure being the increase in its level. As can be seen from Table I, in thirteen of the patients who showed a change in the $\mathrm{T}$ wave, and in whom figures are available for the serum potassium both before and during the administration of potassium salts, the rise in the serum potassium varied from 1.9 to $15.8 \mathrm{mg}$. per 100 c.c., the average being $8.3 \mathrm{mg}$., while the comparable figures for the patients with no change in the $\mathrm{T}$ wave were $-0 \cdot 3$ to $7.1 \mathrm{mg}$. per 100 c.c., giving an average of $2.6 \mathrm{mg}$. In only one instance did the serum potassium fail to return to practically the original level, and in this case the $\mathrm{T}$ wave also failed to return to its original height.

This heightening of the $\mathrm{T}$ wave was accompanied by a slight or moderate elevation of the S-T segment in a few of the patients (Fig. 1), and inversion occurred in one case (Fig. 2).
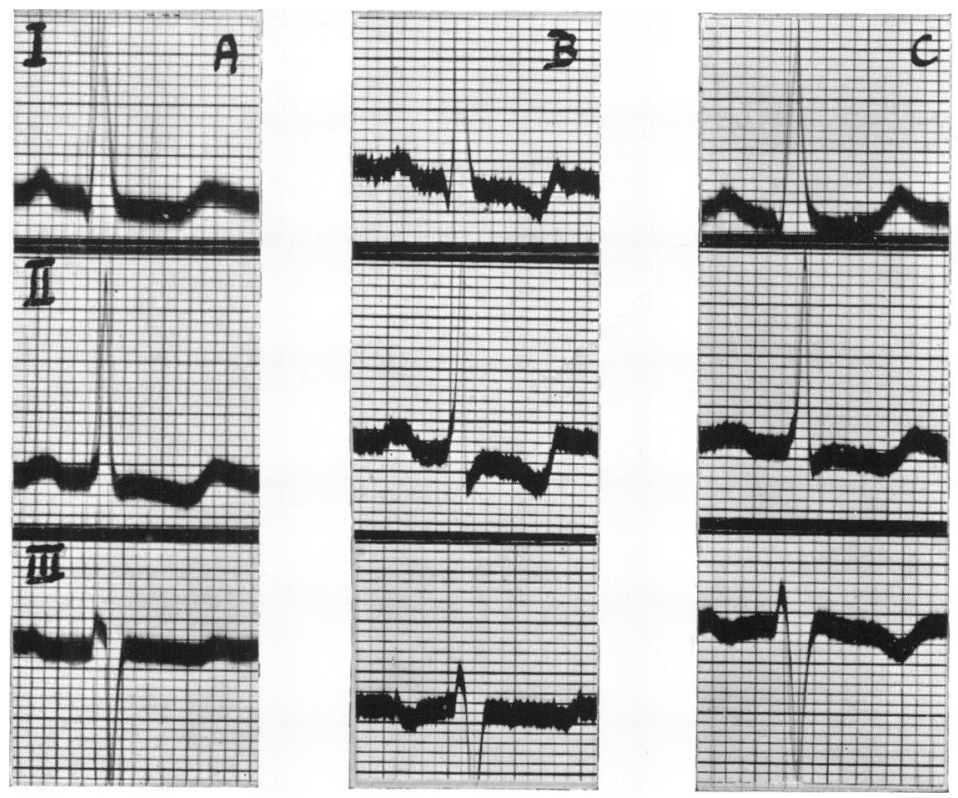

FIG. 2.-Electrocardiograms from Case 12, with luetic aortic incompetence.

(A) Before administration of potassium salts.

(B) After $192 \mathrm{~g}$. of potassium citrate given during 14 days, showing $\mathrm{T}$ 'waves increasingly diphasic in all leads (serum potassium increased from 17.8 to $31.8 \mathrm{mg}$. per 100 c.c.).

(C) After 7 days without any potassium salts, when the $T$ waves were almost, and the serum potassium was quite, back to the original levels. 
No constant change was found in any instance in the levels of the serum sodium or calcium or the blood urea.

\section{(B) Potassium and Conduction}

In two patients the administration of potassium salts was accompanied by impairment of conduction, and, in view of the importance of these observations, it is proposed to describe them in detail.

Case 23. A woman, aged 45, gave a three years' history of short attacks of palpitation, which began and ended gradually. She had lost weight, and had some symptoms suggestive of thyrotoxicosis, but on examination no evidence of this could be found and the basal metabolic rate was only +12 per cent. The blood pressure was $145 / 90 \mathrm{~mm}$., the pulse was 96 , and regular, the heart was not enlarged, and the heart sounds were pure and clear. A diagnosis of the menopausal syndrome was made. Serum potassium was $16.4 \mathrm{mg}$.; serum calcium, $11.9 \mathrm{mg}$. ; blood urea $20 \mathrm{mg}$., in each case, per 100 c.c.

Potassium chloride was given in doses of $5 \mathrm{~g}$. thrice daily, combined after one day with the same amount of potassium citrate. During the second night
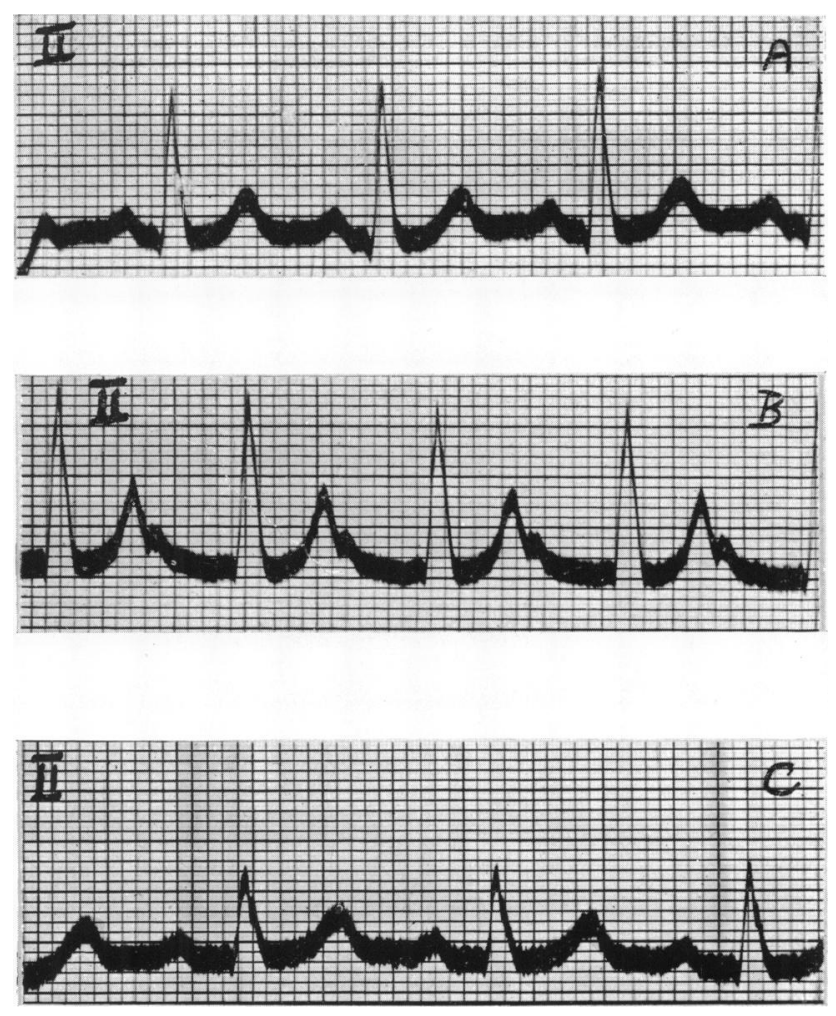

FIG. 3.-Electrocardiograms in Case 23.

(A) Showing the P-R interval within normal limits.

(B) Three days later, after the patient had received $40 \mathrm{~g}$. of potassium chloride and $15 \mathrm{~g}$. of potassium citrate, showing lengthening of P-R interval and heightened $T$ wave.

(C) Seven days from the start, when no potassium salts had been given for three days, showing the P-R interval again within normal limits and the T wave back to its original height. 
of potassium administration, after she had received $35 \mathrm{~g}$. of the chloride and $10 \mathrm{~g}$. of the citrate, she complained of a heavy feeling in the legs, and the pulse was found to be 120 per minute and regular. Next day, three hours after another $5 \mathrm{~g}$. each of the chloride and the citrate, there was prolongation of the P-R interval and heightening of the $T$ wave (Fig. 3 B). Potassium salts were stopped on the fourth day, when the patient felt very hot and flushed and complained of a sinking feeling, nausea, and a tingling sensation in the arms, but not of palpitation.

Three days later the P-R interval had become normal (Fig. $3 \mathrm{C}$ ) and remained so in a subsequent record.

Case 11. A woman, aged 46, was admitted on account of increasing dyspnœa on exertion and cough ; during the last three months orthopnœa and swelling of the ankles had developed.

On examination she was found to be a typical case of mitral stenosis with normal rhythm and signs of early congestive heart failure.

The serum potassium was $20.6 \mathrm{mg}$. ; serum calcium, $10.1 \mathrm{mg}$.; and the blood urea $39 \mathrm{mg}$., in each case, per 100 c.c. Hæmoglobin, 100 per cent.

After a week in hospital, the administration of potassium chloride was started in doses of $5 \mathrm{~g}$. thrice daily. Two hours after the fourth dose she felt cold and sick and complained of a sensation of tingling everywhere and of sinking through the bed; the pulse was 112 per minute and regular. An hour later, while still regular, it had fallen to 40 , rising two hours later to 60 per minute and still regular. On the following day, that is after the patient had taken $30 \mathrm{~g}$. of potassium chloride in all, it was stopped on account of vomiting and evacuation of the bowels, the pulse being 42 per minute and regular.

Eight days later, the serum potassium being $19 \mathrm{mg}$. per 100 c.c., administration of potassium salts was begun again, and during the next sixteen days $125 \mathrm{~g}$. of potassium citrate was given without the production of any toxic effects. On the seventeenth day potassium chloride, in doses of $3 \mathrm{~g}$. thrice daily, was combined with the citrate which was now being given in doses of $5 \mathrm{~g}$. thrice daily, and the following day, twenty-five minutes after her second dose of each of these salts, she complained of feeling queer and the pulse was found to be 72 per minute and regular. Fifty minutes later it was 30 and regular, the patient complaining of no discomfort ; and after another thirty minutes the pulse was 44 , while an hour later it was 56 per minute and regular.

In view of these signs of toxicity, it was decided to follow the course of their development more carefully by giving the patient a dose of the two salts and following the effect on the heart by means of the electrocardiograph and by recording the rate of the heart at the apex every minute. Accordingly, the next day, after a control electrocardiogram showing normal sinus rhythm (Fig. $4 \mathrm{~A}$ ), a sample of blood was obtained which gave the following results, serum potassium, $19 \cdot 1 \mathrm{mg}$. ; serum calcium, $11.6 \mathrm{mg}$. ; blood urea, $30 \mathrm{mg}$., in each case, per 100 c.c. The patient was then given $5 \mathrm{~g}$. of potassium chloride and $5 \mathrm{~g}$. of potassium citrate by mouth. Thirty minutes later there was some increase in the height of the $T$ wave. Forty-three minutes after the ingestion of the potassium salts, the ventricular rate suddenly slowed and became irregular, 
and there were two periods of cardiac asystole and slight prolongation of the P-R interval (Fig. 4 B). (It should be noted that T III was negative in the control). Venu-puncture was performed as soon as this electrocardiogram was taken and the serum potassium was $28.9 \mathrm{mg}$. ; serum calcium, $11.5 \mathrm{mg}$. ; and the blood urea, $34 \mathrm{mg}$., in each case, per 100 c.c.; the patient complained of feeling faint, but objectively the only change noted was deepening of the respirations and some pallor of the face.
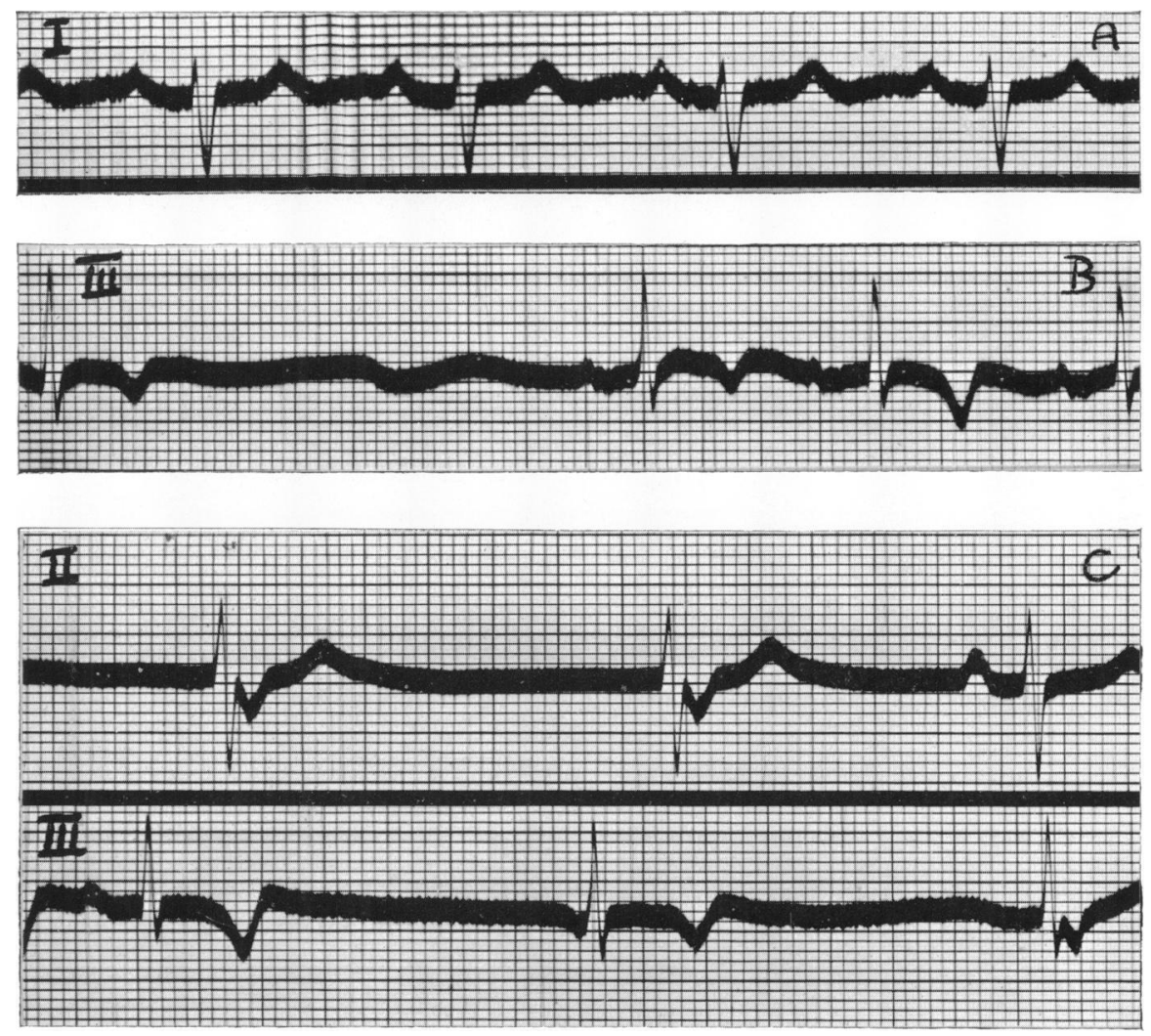

FIG. 4.-Electrocardiograms in Case 11.

(A) Prior to administration of potassium, showing normal sinus rhythm.

(B) 43 minutes after administration of $5 \mathrm{~g}$. of potassium chloride and $5 \mathrm{~g}$. of potassium citrate, showing period of cardiac asystole.

(C) 71 minutes after administration of potassium, showing bradycardia with varying sites of impulse formation.

On account of the persistent bradycardia and irregularity, atropine sulphate gr. 1/50 was given subcutaneously eight minutes later, that is fifty-one minutes after the ingestion of the potassium salts, and an electrocardiogram two minutes later showed similar changes to the previous one. Others were taken subsequently, one of which, seventy-one minutes after the ingestion of the potassium salts, is reproduced in Fig. $4 \mathrm{C}$ and shows a shifting pacemaker, situated sometimes in the A-V node, sometimes in the S-A node. In lead I of this electrocardiogram, which is not reproduced, ventricular complexes occur without any associated $P$ waves. When observations were discontinued, 107 minutes after 
the ingestion of the potassium salts, the ventricular rate was 72 per minute and regular. An electrocardiogram taken nearly four hours after the beginning of the experiment revealed normal sinus rhythm with the $\mathrm{T}$ waves still heightened; six days later another was essentially similar to the control record, and analysis of the blood showed that it was practically the same as before the administration of potassium, i.e. serum potassium $17.0 \mathrm{mg}$., serum calcum $10.5 \mathrm{mg}$. and blood urea $42 \mathrm{mg}$., in each case per 100 c.c.

In this patient potassium salts produced changes in intracardiac conduction, just over forty minutes after their ingestion, changes which the electrocardiogram showed, consisted principally of suppression of the sinus as the inaugurator of the cardiac impulse, this function being finally taken over by either the A-V node or bundle. Two points of interest are that conduction in the ventricles was not affected, and that when the sinus again took over its normal function as pacemaker there was no evidence of more than a very slight delay in conduction between the auricles and ventricles.

\section{(C) OTHER Signs of ToXicity}

Apart from the effects on the heart just described, few definite signs of toxicity were observed from giving potassium salts. All the patients disliked the taste of the chloride mixture, a taste which it is wellnigh impossible to disguise. Vomiting occurred in five patients, but generally in those with malignant hypertension or chronic nephritis, in whom the least disturbance was liable to produce vomiting, and in only one of these was it persistent. Only one patient complained of symptoms that might be cardiac, namely thumping of the heart. Three, including the two described in the preceding section, complained of tingling in the arms and legs followed by a sensation as if the limbs were dead or heavy ; and sweating occurred in one. Diarrhœa was not encountered in any of the patients.

\section{Discussion : (A) Potassium and the T Wave}

During the last sixty years the effect of the inorganic cations, including potassium, upon the heart has been very fully studied by the physiologists, notably Ringer (1880-82), Howell (1899, 1902, 1905-06), Greene (1899), Hald (1905), and Hering (1915). All these, however, have made use of the experimental animal, including the frog, rabbit, cat, and dog, and little work has been done upon the effects of these cations on the human heart, the inference having been accepted that comparable effects might be expected in the case of man.

One of the few investigations carried out in man is that of Harris and Levin (1937), who injected various amounts of a 5 per cent. solution of potassium chloride into six normal subjects and reported that the height of $T$ was sometimes increased, but that " no definite correlation could be found between the magnitude of the changes in the electrocardiogram and the concentration of potassium in the blood stream." The two most direct studies with the experimental animal have been those of McLean and his colleagues (1933) and of Winkler and his colleagues (1938). The former, working with the perfused rabbit's heart, showed that increasing the potassium content of the perfusing fluid resulted in a high $\mathrm{T}$ wave, and diminution in a low or negative $\mathrm{T}$ wave. 
Winkler, Hoff, and Smith (1938) injected isotonic solutions of potassium chloride intravenously into dogs and found that the first change to occur was an increase in the height of the $\mathrm{T}$ wave, which progressed until $\mathrm{T}$ equalled the QRS complex in amplitude. Wiggers (1930) also has shown that the intravenous injection of potassium chloride in the dog is followed by a pronounced increase in the height of $\mathrm{T}$.

It is not proposed here to discuss all the factors that are known to cause an increase in the height of the $\mathrm{T}$ wave, but some of them appear to have a bearing on the present problem, and among these one of the most important is the effect of asphyxia on the heart. As has been shown by D'Silva (1934) and Cattel and Civin (1938) in the case of the cat, and by Dennis and Mullin (1938) in the case of the dog, asphyxia results in an increase in the concentration of the serum or plasma potassium. Most workers are agreed that asphyxia results in an increase in the height of the $T$ wave. Thus Greene and Gilbert (1922), producing anoxæmia in dogs by a rebreathing method, found that as the anoxæmia developed the most typical change in the electrocardiogram was that $\mathrm{T}$ became increasingly taller till it was as high as the original $\mathrm{R}$ wave, and that this change "apparently did not depend on a change in the position of the heart." Similar results were obtained in dogs by Haggard (1921), and Kountz and Hammouda (1932), working with a heart-lung preparation in the same animal, found that excess of carbon dioxide increased the height of $\mathrm{T}$ in all leads.

Similar changes in the $\mathrm{T}$ wave have been obtained in alkalosis and acidosis. Barker, Shrader, and Ronzoni (1939) found in man that alkalosis resulted in a lowering of the $\mathrm{T}$ wave, the opposite effect being produced by acidosis. In dogs Schott (1926) reported that the intravenous injection of hydrochloric acid was followed by a rise, and of sodium bicarbonate by a fall in the height of the T wave. Carter, Andrus, and Dieuaide (1924) found that upright T waves in the cardiogram of a dog being perfused with a solution of $\mathrm{pH} 7 \cdot 1$ became negative when the reaction of the perfusate was made less acid ( $\mathrm{pH} 7 \cdot 4$.) Allott and McArdle (1938) report that in a severe case of tetany and alkalosis due to vomiting from pyloric obstruction the serum potassium was as low as $7.6 \mathrm{mg}$. per 100 c.c., which is of interest in this connection.

Pitressin has also been shown to cause an increase in the height of the $T$ wave in dogs (Resnik and Geiling (1924-25), Gruber and Kountz (1930), and Melville (1938) ), and this and the other effects on the heart have been attributed by these authors to anoxæmia of the heart. D'Silva (1934) found that pitressin caused a rise in the serum potassium.

In view of these findings, namely that an increase in the height of the $T$ wave is caused by asphyxia, acidosis, pitressin, and potassium, taken in conjunction with the correlated changes in the level of the serum potassium, there would seem to be some justification for the hypothesis that the common factorpotassium-may be the cause of these changes. Andrus and Carter (1924) in their work on the effect of changes in $\mathrm{pH}$ upon the heart suggested that these changes might be elicited by a disturbance of ionic equilibrium between the cell contents and the tissue fluid, and, in view of the fact that potassium is dominantly an intracellular ion, it is only to be expected that any such dis- 
turbance of ionic equilibrium might be accompanied by an increase of potassium in the extracellular fluids, including the bloodstream. Whether potassium acts directly or indirectly, and the mechanism of its action are questions which can be discussed more conveniently in association with the changes produced in intracardiac conduction.

\section{(B) Potassium and Conduction}

As the two cases just described show, the effects of potassium on the heart in man are comparable with those in the experimental animal, the main difference being that in man there is much less effect on the ventricle. This is probably due to the fact that much larger amounts are needed to affect the ventricle in man than it would be possible to give with safety.

The problem which is of outstanding interest here is the mechanism whereby potassium produces these effects. Is the block due to a direct effect of potassium upon the myocardium, or is it an indirect effect mediated through the vagus? That there is a close association between the effects of the vagus and of potassium on the heart has been suggested by many workers since the original work of Howell (1905-06) who showed in frogs and terrapins that an increase of potassium in the circulating medium enhanced the sensitiveness of the heart to vagus inhibition, and interpreted these results as meaning that the vagus impulses act indirectly by increasing the amount of diffusible potassium compounds in the heart tissue. Subsequently (Howell and Duke, 1908) he found that in the isolated mammalian heart stimulation of the vagus caused an increase in the potassium content of the circulating medium. Among more recent workers who have confirmed these findings may be quoted Herz (1935) who found that potassium ions have a marked effect upon the sensitivity of the heart of the frog to vagal stimulation, and Lenhartz (1936) who found in the isolated auricle of the tortoise an increase in the potassium content of the perfusion fluid following stimulation of the vagus.

A similar close association has been shown to exist between acetylcholine and potassium. Thus in the heart of the frog, Chang and Gaddum (1933) found that potassium produced effects similar to those given by acetylcholine. In the cat, Brown and Feldberg (1936) found that potassium increased the response of the superior cervical ganglion to preganglionic stimuli and liberated acetylcholine from the ganglion, while Feldberg and Guimaräis (1936), finding that intra-arterial injections of potassium chloride liberated acetylcholine from various organs, consider this supports the suggestion that discharge of acetylcholine may be effected by potassium ions mobilized in the passage of the nerve impulse. Fischer (1936) has suggested that different vagal fibres affecting the heart are not only functionally different, but that there exist several chemical transmitters for the vagal action, one of which is potassium and another acetylcholine.

Further light is thrown on the problem by the careful study of Greene and Gilbert (1922) of the effects of anoxæmia on the heart. Working with the dog and producing a gradually increasing anoxæmia, they found that this inhibited sino-auricular rhythm or drove the rhythm to a lower focus in the 
tail of the sino-auricular node. When sino-auricular rhythm was inhibited, an auriculo-ventricular rhythm became dominant, but at a slower rate. If at this stage the anoxæmia was relieved, normal rhythm was restored, but, if the anoxæmia was allowed to develop, the rhythmic centre was driven down into the left bundle branch. Section of both vagi invariably abolished these early changes and was followed by the onset of sinus tachycardia. They therefore concluded that the early anoxæmic changes were a vagal effect, and that it was only when an extreme degree of anoxæmia was produced that suppression of rhythm was obtained due to cardiac anoxæmia. Their criticism of other workers, such as Mathison (1910-11), who considered that the heart block of asphyxia was not due to a vagal effect, was that these workers had used such rapid methods of inducing anoxæmia that they missed the early stage of slowing due to the vagus and only obtained the late stage of direct cardiac anoxæmia. The interest of these findings of Greene and Gilbert is that the changes they produced in the heart were very similar to those obtained in our second case. In both instances there was suppression of the sino-auricular node as pacemaker, the auriculo-ventricular node taking on this function, and in both the first change was a heightening of the $T$ wave. It was on these grounds that atropine was administered at the height of the block in our case, but in view of our ignorance as to how long the potassium effect persists it is not possible to decide whether the return of normal sinus rhythm was due to the atropine or not.

In other words we find that vagal stimulation and acetylcholine and potassium all produce the same effects on the heart, and that the two former increase the extracellular concentration of potassium. Further Lenhartz (1936) has shown in the isolated auricles of the heart of the tortoise that when enough atropine is present to suppress the inhibitory action of vagal stimulation and of acetylcholine, neither of these last procedures produced any change in the concentration of potassium ions. There would therefore seem to be justification for advancing the hypothesis that these particular changes in the function of the heart are mediated through the action of the potassium ion. The exact mechanism of this action still awaits further elucidation.

\section{Clinical Applications}

While the pathological aspects of the relationship of potassium to cardiac pathology raise many interesting problems, with which it is not intended to deal here, there is a clinical aspect, now being investigated, which would seem to be worthy of attention.

Potassium salts, particularly in the form of the citrate, have long enjoyed a reputation as diuretics both in renal and cardiac œdema. The dose of potassium citrate, according to the British Pharmacopœia, is 10-60 grains (0.65-4 g.). Potassium chloride is included in the British Pharmaceutical Codex, where the dose of this salt is given as 15-60 grains (1-4 g.). As a rule, however, much larger doses are prescribed. Thus Blum (1920) gave $25 \mathrm{~g}$. of the chloride daily in cases of chronic nephritis, while Osman (1927) gave his patients with Bright's disease $24 \mathrm{~g}$. of potassium salts (12 g. of citrate and $12 \mathrm{~g}$. of bicarbonate) daily. Keith and Binger (1935) recommended a standard daily dose equivalent to 
$5 \mathrm{~g}$. of potassium ( $10 \mathrm{~g}$. of chloride or $14 \mathrm{~g}$. of citrate), and even larger amounts were given by Hawes and Vardy (1935) in nephrosis, a mixture containing $2 \mathrm{~g}$. of potassium bicarbonate and $2 \mathrm{~g}$. of citrate, every hour for long periods.

The general assumption has been that large doses of potassium salts by mouth are not toxic on account of the rapidity with which they are excreted in the urine. To quote the British Pharmaceutical Codex (1934), "Potassium chloride does not exhibit the depressant action of the potassium ion on the tissues, because it is excreted with such extreme rapidity that the blood never contains it in sufficient concentration to produce the specific effect." That this is not always the case, however, is shown by the figures in our cases, and particularly is this so in chronic nephritis, the very group in which potassium salts are usually administered as diuretics. In view of the marked disturbances which can be produced by the ingestion of potassium salts by mouth, their administration in patients with cardiovascular disease would seem to be contraindicated, or at least they should only be given in small doses. A consideration of the treatment of the large number of elderly patients with enlargement of the prostate, who are given mixtures containing anything from $4 \mathrm{~g}$. (60 grains) of potassium citrate three or four times a day both before and after operation, raises the interesting question as to the effect of such medication on a heart that is often far from healthy. Is this the solution of the problem as to why some of these patients occasionally die suddenly?

A further clinical application is suggested by Camp's (1939) work on the potentiation of digitalis action by potassium. This investigator found in dogs that the administration of three or four doses of digitalis given every five minutes was without effect on the pulse or amplitude. If potassium chloride was given at this stage, however, marked slowing of the pulse occurred accompanied by an increase of amplitude. He suggests that digitalis exerts an early unrecognizable action on the heart which can be made manifest by potassium.

\section{SUMmary.}

1. Potassium salts, in the form of the chloride and the citrate in doses varying from 3-30 g. daily, have been given to twenty-four patients with various diseases, and the effect on the electrocardiogram has been observed.

2. In fourteen of these the administration of potassium salts was followed by an increase in the height of the $\mathrm{T}$ wave in one or more leads. No correlation was found between the increase in the height of the $T$ wave on the one hand and the amount of potassium given or the increase in the concentration of the serum potassium on the other, except that in the fourteen patients who showed this change the average increase in the level of the serum potassium was $8.3 \mathrm{mg}$. per 100 c.c., compared with $2.6 \mathrm{mg}$. per 100 c.c. in the patients who showed no such change.

3. In one patient the $T$ wave, which was diphasic in all leads before the administration of potassium salts, became more deeply diphasic while they were being given.

4. In two patients definite degrees of heart block were produced by the administration of potassium salts. In one, there was prolongation of the P-R 
interval, while in the other sino-auricular block and nodal rhythm resulted with marked slowing and irregularity of the heart rate.

5. The similarity of these changes to those produced by vagal stimulation, by acetylcholine, and by pitressin is discussed, and the hypothesis is advanced that in each case they may be mediated through the action of the potassium ion on the myocardium.

6. Certain clinical applications of this work are also discussed, and it is recommended that potassium salts should be used with the utmost caution in patients with cardiovascular or renal disease.

I am indebted to Professor O. L. V. S. de Wesselow for permission to carry out these investigations on patients under his care and for the interest which he has taken throughout this work.

\section{REFERENCES}

Allott, E. N., and McArdle, B. (1938). Clin. Sci., 3, 229.

Andrus, E. C., and Carter, E. P. (1924). Heart, 11, 97.

Barker, P. S., Shrader, E. L., and Ronzoni, E. (1939). Amer. Heart J., 17, 169.

Blake, J. (1839). Edinb. Med. and Surg. J., 51, 330.

Blum, L. (1920). Presse méd., 28, 685.

British Pharmaceutical Codex (1934). London

Brown, G. L., and Feldberg, W. (1936). J. Physiol., 86, 290.

Butler, A. M., and Tuthill, E. (1931). J. Biol. Chem., 93, 171.

Camp., W. J. R. (1939). Arch. Internat. de Pharmacodyn., 61, 60.

Carter, E. P., Andrus, E. C., and Dieuaide, F. R. (1924). Arch. intern. Med., 34, 669.

Cattell, McK., and Civin, H. (1938). J. biol. Chem., 126, 633.

Chang, H. C., and Gaddum, J. H. (1933). J. Physiol., 79, 255.

Clark, E. P., and Collip, J. B. (1925). J. biol. Chem., 63, 461.

Dennis, J., and Mullin, F. J. (1938). Proc. Soc. exp. Biol. N. Y., 38, 560.

D'Silva, J. L. (1934). J. Physiol., 82, 393.

Feldberg, W., and Guimarāis, J. A. (1936). J. Physiol., 86, 306.

Fischer, E. (1936). Amer. J. Physiol., 117, 596.

Greene, C. W. (1899). Ibid., 2, 82.

Greene, C. W., and Gilbert, N. C. (1922). Ibid., 60, 155.

Gruber, C. M., and Kountz, W. B. (1930). J. Pharmacol., 40, 253.

Haggard, H. W. (1921). Amer. J. Physiol., 56, 390.

Hald, P. T. (1905). Arch. exp. Path. Pharmak., 53, 22.

Harris, I., and Levin, D. A. (1937). J. Physiol., 89, 153.

Hawes, R. B., and Vardy, E. C. (1935). Quart. J. Med., 4 (N.S.), 1.

Hering, H. E. (1915). Pflug. Arch. ges. Physiol., 161, 537, 544.

Herz, W. (1935). Ibid., 236, 298.

Howell, W. H. (1899). Amer. J. Physiol., 2, 47

- (1902). Ibid., 6, 181.

(1905-06). Ibid., 15, 280.

and Duke, W. W. (1908). Ibid., 21, 51.

Keith, N. M., and Binger, M. W. (1935). J. Amer. med. Ass., 105, 1584.

Kountz, W. B., and Hammouda, M. (1932). Amer. Heart J., 8, 259.

Kramer, B., and Tisdall, F. F. (1921). J. biol. Chem., 46, 339. (1921). Ibid., 47, 495 .

Lenhartz, E. (1936). J. Physiol., 86, 37P.

McLean, F. C., Bay, E. B., and Hastings, A. B. (1933). Amer. J. Physiol. 105, 72.

Magnus-Levy, A. (1920). Dtsch. med. Wschr., 46, 594.

Mathison, G. C. (1910-11). Heart, 2, 54.

Melville, K. I. (1938). J. Pharmacol., 64, 86.

Osman, A. A. (1927). Guy's Hosp. Rep., 77, 386.

Peters, J. P., and Van Slyke, D. D. (1932). Quantitative Clinical Chemistry, vol. ii, London

Resnik, W. H., and Geiling, E. M. K. (1924-25). J. Clin. Invest., 1, 217.

Ringer, S. (1880-82). J. Physiol., 3, 380.

Schott, E. (1926). Dtsch. Arch. klin. Med., 152, 287.

Smillie, W. G. (1915). Arch. intern. Med., 16, 330.

Thomson, W. A. R. (1939). Lancet, 1, 808.

Webster, R. W. (1927). Potassium and Tartrates : a Review on Their Physiological Effects, Chicago.

Wiggers, C. J. (1930). Amer. J. Physiol., 93, 197.

Winkler, A. W., Hoff, H. E., and Smith, P. K. (1938). Ibid., 124, 478. 